\title{
Biological Parameters of the Bark Beetle, Xylosandrus crassiusculus (Motschulsky) Under Controlled Laboratory Conditions
}

\author{
Khalid Hussain Qureshi ${ }^{1}$, Abdul Waheed Solangi ${ }^{1}$, Abdul Ghani Lanjar ${ }^{1}$, Jan Muhammad Marri ${ }^{1}$, \\ Sajjad Ali Khuhro ${ }^{2}$ and Aslam Bukero ${ }^{3}$ \\ (1) Department of Plant Protection, Sindh Agriculture University, Tandojam-Pakistan, Email: waheedsolangi@ sau.edu.pk; \\ awaheed334@yahoo.com; (2) Department of Agriculture, Mir Chakar Khan Rind University, Sibi, Balochistan-Pakistan; \\ (3) Department of Entomology, Sindh Agriculture University, Tandojam-Pakistan.
}

\begin{abstract}
Qureshi, K.H., A.W. Solangi, A.G. Lanjar, J.M. Marri, S.A. Khuhro and A. Bukero. 2021. Biological Parameters of the Bark Beetle, Xylosandrus crassiusculus (Motschulsky) Under Controlled Laboratory Conditions. Arab Journal of Plant Protection, 39(2): 146-151.

Biological parameters of the bark beetle, Xylosandrus crassiusculus (Motschulsky) (Coleoptera: Curculionidae: Scolytinae) was investigated under different temperature regimes $\left(27,29,31\right.$ and $\left.35^{\circ} \mathrm{C}\right)$. The females reared at $29^{\circ} \mathrm{C}$, lived $30.93 \pm 2.36$ days for oviposition. The female laid a maximum of $6.71 \pm 1.89$ eggs per day and a maximum of $6.99 \pm 1.33$ batches per female. Each batch had an average of $13.78 \pm 2.01$ eggs. The mean total fecundity recorded was $67.8 \pm 4.25$ eggs, with a shortest egg incubation period. At $29^{\circ} \mathrm{C}$, the duration of the larval stage was $20.17 \pm 2.89$ days, the pupal stage 5.03 \pm 1.11 days, and the life span of the adult insect was $29.44 \pm 3.19$ days. Significant differences $(\mathrm{P}<0.05)$ were noted when the duration of the different life stages under 29 and $35^{\circ} \mathrm{C}$ were compared, with longer duration at $29^{\circ} \mathrm{C}$. Insects reared at $35^{\circ} \mathrm{C}$ had narrower bodies and smaller sizes. Furthermore, the developmental stages period, including the ovipositional period (days) were negatively correlated with temperature.

Keywords: Xylosandrus crassiusculus, bark beetle, biological parameters, temperature regimes.
\end{abstract}

\section{Introduction}

Mango (Mangifera indica L., Anacardiaceae) is a major fruit crop in tropical and subtropical areas of the world (Masood et al., 2010). Mango production has been decreased due to different biotic and abiotic factors (Jiskani et al., 2007). Mango sudden death syndrome (MSDS) is one of the major threats of the mango industry (Khuhro et al., 2005). In Pakistan, the yield of mango trees has been reduced by primary insect pests such as mealybug (Drosicha mangiferae) (Green), hopper (Idioscopus clypealis), midge (Erosomya indica), scale insect (Aulacaspis tubercularis) and the fruit fly (Bactrocera dorsalis) (Brown et al., 2006).

Bark beetles (Coleoptera: Scolytidae) are the most important forest insect pests, as more than 6000 species have been recorded in tropical and sub-tropical regions of the world (Kazmi et al., 2005). The mango bark beetle, Xylosandrus crassiusculus (Motschulsky) (Coleoptera: Curculionidae: Scolytinae) has frequently been found on diseased mango trees (Saeed et al., 2011). The biology of $X$. crassiusculus is very important, especially investigations of it's role as a pest and as a possible carrier of MSDS. Effect of abiotic factors such as temperature on biological parameters of the bark beetle i.e. developmental time, life time, egg production, sex ratio, life span and morphological characteristics of the beetle were investigated (Hanula el al., 2008). Cool or warm environment can have adverse effects on life history traits of the beetle (Steininger et al., 2015) and optimum temperature is required for the proper development of the beetle (Ranger et al., 2010). Temperatures may be too low for metabolic reactions in beetles (Werle et al., 2016). Successful ambrosia beetle dispersal depends on suitable temperature, light intensity, wind direction and speed (Gandhi et al., 2010). All of these factors can affect the ability of the females to detect and orient towards stress volatiles from a new host. This is known as directed dispersal and it provides a greatest opportunity for successful colonization. Temperature is an important factor, if it is too cold, metabolic reactions necessary for flight may be compromised, and the ectothermic beetles may be unable to adequately operate flight muscles (Ranger et al., 2013). Adults emergence depends mostly on air temperature in April-May every year (Mizell and Riddle, 2004). There is almost no systematic information on the biological parameters of $X$. crassiusculus in Sindh, except few reports related to its population in mango orchards (Khuhro et al., 2005). In the present study, the life cycle and some biological parameters of $X$. crassiusculus at different temperature combinations under controlled laboratory conditions were investigated.

\section{Materials and Methods}

Biological parameters of $X$. crassiusculus was investigated at IPM Laboratory, Plant Protection Department, Sindh Agriculture University Tandojam-Pakistan during April, 2018. The laboratory stock culture of $X$. crassiusculus was maintained by placing infected logs $(40-50 \mathrm{~cm}$ long and 20 $\mathrm{cm}$ in diameter), brought from the mango orchards of malir farm of Sindh Agriculture University, Tandojam and were 
kept in insect rearing chamber in the laboratory. A transparent collecting jar was fitted at the bottom end with an artificial light source. At 11 days intervals, 4-5 fresh logs were introduced to infected logs for the maintenance of stock culture. The life history traits of bark beetle were studied, using the disc method (Masood et al., 2009; Kendra et al. 2012; Gurpreet et al., 2013). The size of discs used was $4 \mathrm{~cm}$ in diameter and $2 \mathrm{~cm}$ thick, were cut from uninfected and healthy-looking mango tree stems by using a sharp knife. The newly hatched beetles were collected from the tree logs and reared on modified mango discs, at the rate of one pair $(1: 1)$ per disc. Each disc was then placed singly in a pressed thermopore glass having a filter paper at the base to absorb excessive moisture, to prevent the development of fungal growth. The discs were then placed in the incubating chambers at $27^{\circ} \mathrm{C}, 29^{\circ} \mathrm{C}, 31^{\circ} \mathrm{C}$ and $35^{\circ} \mathrm{C}$ at $70 \% \mathrm{RH}$. A total of 100 discs were used at each treatment. For daily observation, prepared discs were separated by the help of a sharp knife to investigate the different life stages of the beetle for each treatment. Two experiments were conducted; i) biological parameters (days) and fecundity of the bark beetle under different temperature regimes and ii) body size from egg to adult stage at the 2 temperature regimes 29 and $35^{\circ} \mathrm{C}$ only. Morphology of all the stages were investigated with the help of a magnified glass and under the stereomicroscope. The $1^{\text {st }}$ and $5^{\text {th }}$ larval instars were distinguished from each other based on molting and head capsule width by using a microscope with ocular micrometer (Fernandez et al., 1999).

\section{Statistical analysis}

Biological parameters under different temperature regimes were compared through one-way analysis of variance (ANOVA) using least significant differences (LSD). However, the correlation between developmental period (days), ovipositional period (days) and fecundity of all treatments were estimated by using XLSTAT version 2018. The body size as affected by the two treatments (29 and $35^{\circ} \mathrm{C}$ ) was analyzed by using a t-test. All statistical analyses were done through SPSS version 21 (IBM SPSS).

\section{Results}

\section{Developmental period of $X$. crassiusculus}

Temperature had a significant effect on the life history traits of the $X$. crassiusculus. The shortest egg incubation period was $04.01 \pm 1.99$ days at $29^{\circ} \mathrm{C}$, followed by $7.22 \pm 1.02$ days at $27^{\circ} \mathrm{C}, 5.12 \pm 1.09$ days at $31^{\circ} \mathrm{C}$ and $6.22 \pm 1.10$ days at $35^{\circ} \mathrm{C}$. The shortest larval stage duration was $20.17 \pm 2.89$ days at $29^{\circ} \mathrm{C}, 25.17 \pm 2.06$ days at $27^{\circ} \mathrm{C}$, followed by $21.19 \pm 2.06$ days at $31^{\circ} \mathrm{C}$ and $22.17 \pm 3.25$ days at $35^{\circ} \mathrm{C}$. However, the shortest duration of the pupal stage was $5.03 \pm 1.11$ days at $29^{\circ} \mathrm{C}$ followed by $9.11 \pm 1.89$ days at $27^{\circ} \mathrm{C}, 7.08 \pm 1.99$ days at $31^{\circ} \mathrm{C}$ and $6.01 \pm 1.81$ days at $35^{\circ} \mathrm{C}$ (Table 1). The longest adult stage was $29.44 \pm 3.19$ days at $29^{\circ} \mathrm{C}$ and $26.74 \pm 2.56$ days at $31^{\circ} \mathrm{C}$, followed by $26.03 \pm 1.58$ days at $35^{\circ} \mathrm{C}$ and $25.54 \pm 2.41$ days at $27^{\circ} \mathrm{C}$.

Table 1. Mean value $( \pm \mathrm{SE})$ of biological parameters of $X$. crassiusculus reared at different temperature regimes under controlled laboratory conditions.

\begin{tabular}{|c|c|c|c|c|c|}
\hline Parameters & $27^{\circ} \mathrm{C}$ & $29^{\circ} \mathrm{C}$ & $31^{\circ} \mathrm{C}$ & $35^{\circ} \mathrm{C}$ & $\mathbf{P}$ \\
\hline Egg incubation period (days) & $\begin{array}{c}7.22 \pm 1.02 \mathrm{a} \\
(6-9)\end{array}$ & $\begin{array}{c}04.01 \pm 1.99 \mathrm{c} \\
(2-5)\end{array}$ & $\begin{array}{c}5.12 \pm 1.09 \mathrm{bc} \\
(4-6)\end{array}$ & $\begin{array}{c}6.22 \pm 1.10 \mathrm{~b} \\
(5-7)\end{array}$ & $<0.0001$ \\
\hline Larval duration (days) & $\begin{array}{c}25.17 \pm 2.06 \mathrm{a} \\
(22-27)\end{array}$ & $\begin{array}{c}20.17 \pm 2.89 \mathrm{c} \\
\quad(17-23)\end{array}$ & $\begin{array}{c}21.19 \pm 2.06 \mathrm{~cd} \\
\quad(18-22)\end{array}$ & $\begin{array}{c}22.17 \pm 3.25 b \\
(5-7)\end{array}$ & $<0.001$ \\
\hline Pupal duration (days) & $\begin{array}{c}9.11 \pm 1.89 a \\
(7-11)\end{array}$ & $\begin{array}{c}05.03 \pm 1.11 \mathrm{c} \\
(4-7)\end{array}$ & $\begin{array}{c}7.08 \pm 1.99 \mathrm{~b} \\
(5-9)\end{array}$ & $\begin{array}{c}6.01 \pm 1.81 \mathrm{ab} \\
(4-7)\end{array}$ & $<0.0017$ \\
\hline Adult longevity (days) & $\begin{array}{c}25.54 \pm 2.41 b c \\
(21-28)\end{array}$ & $\begin{array}{c}29.44 \pm 3.19 \mathrm{a} \\
(26-31)\end{array}$ & $\begin{array}{c}26.74 \pm 2.56 \mathrm{~b} \\
\quad(23-29)\end{array}$ & $\begin{array}{c}26.03 \pm 1.58 \mathrm{ab} \\
(23-29)\end{array}$ & $<0.0023$ \\
\hline Oviposition period (days) & $\begin{array}{c}26.03 \pm 1.29 \mathrm{~b} \\
\quad(24-27)\end{array}$ & $\begin{array}{c}30.93 \pm 2.36 \mathrm{a} \\
(28-33)\end{array}$ & $\begin{array}{c}24.09 \pm 1.99 \text { bc } \\
(21-26)\end{array}$ & $\begin{array}{c}25.13 \pm 1.89 \mathrm{c} \\
(23-27)\end{array}$ & $<0.001$ \\
\hline No. of batches/female & $\begin{array}{c}4.15 \pm 1.01 b c \\
(3-6)\end{array}$ & $\begin{array}{c}07.02 \pm 1.33 \mathrm{a} \\
\quad(5-10)\end{array}$ & $\begin{array}{c}5.05 \pm 1.25 b \\
(4-7)\end{array}$ & $\begin{array}{c}4.20 \pm 1.66 \mathrm{ab} \\
(3-7)\end{array}$ & $<0.0014$ \\
\hline No. of eggs/batch & $\begin{array}{c}10.01 \pm 2.14 \mathrm{c} \\
(8-12)\end{array}$ & $\begin{array}{c}13.78 \pm 2.01 \mathrm{a} \\
(9-15)\end{array}$ & $\begin{array}{c}12.01 \pm 2.74 \mathrm{ab} \\
(10-14)\end{array}$ & $\begin{array}{c}11.88 \pm 2.33 \mathrm{bc} \\
(8-12)\end{array}$ & $<0.0038$ \\
\hline Per day egg laying & $\begin{array}{c}4.01 \pm 0.77 \mathrm{bc} \\
(2-6)\end{array}$ & $\begin{array}{c}06.71 \pm 1.89 \mathrm{a} \\
(4-9)\end{array}$ & $\begin{array}{c}5.02 \pm 0.89 b \\
(3-7)\end{array}$ & $\begin{array}{c}5.01 \pm 0.99 b \\
(3-6)\end{array}$ & $<0.051$ \\
\hline Total fecundity (eggs) & $\begin{array}{c}59.8 \pm 3.25 \text { bc } \\
(34-65)\end{array}$ & $\begin{array}{c}67.8 \pm 4.25 \mathrm{a} \\
(55-80)\end{array}$ & $\begin{array}{c}60.11 \pm 4.25 b \\
(36-62)\end{array}$ & $\begin{array}{c}55.8 \pm 4.25 c \\
(41-60)\end{array}$ & $<0.0001$ \\
\hline
\end{tabular}

Values between brackets represent the range.

Values followed by the same letters in the same row are not significantly different at $\mathrm{P}=0.05$. 


\section{Fecundity of $X$. crassiusculus}

Temperature had a significant effect on the oviposition period of $X$. crassiusculus. The oviposition period was longest $(30.93 \pm 2.36$ days) when females were reared at $29^{\circ} \mathrm{C}$, whereas the shortest period $(26.03 \pm 1.29$ days) was at $27^{\circ} \mathrm{C}$, followed by $25.13 \pm 1.89$ days at $35^{\circ} \mathrm{C}$ and $24.09 \pm 1.99$ days at $31^{\circ} \mathrm{C}$. Each female laid a maximum of $6.71 \pm 1.89$ eggs per day when reared at $29^{\circ} \mathrm{C}$, whereas the lowest per day egg production was $4.01 \pm 0.77$ eggs at $27^{\circ} \mathrm{C}$, followed by $5.01 \pm 0.99$ eggs per day at $35^{\circ} \mathrm{C}$ and $5.02 \pm 0.89$ eggs per day at $31^{\circ} \mathrm{C}$. Females reared at $29^{\circ} \mathrm{C}$ laid a maximum of $07.02 \pm 1.33$ batches per female and a minimum of $5.05 \pm 1.25$ batches/female at $31^{\circ} \mathrm{C}$, followed by $4.20 \pm 1.66$ batches at $35^{\circ} \mathrm{C}$ and $4.15 \pm 1.01$ batches/female at $27^{\circ} \mathrm{C}$. The mean number of eggs laid by a single female was $13.78 \pm 2.01$ eggs per batch when reared at $29^{\circ} \mathrm{C}$, followed by $12.01 \pm 2.74$ eggs/batch at $31^{\circ} \mathrm{C}, 11.1 .88 \pm 2.33$ eggs/batch at $35^{\circ} \mathrm{C}$ and $10.01 \pm 2.14 \mathrm{eggs} / \mathrm{batch}$ at $27^{\circ} \mathrm{C}$. The mean maximum fecundity was $67.8 \pm 4.25$ eggs at $29^{\circ} \mathrm{C}$. Whereas, the lowest egg production recorded was $55.8 \pm 4.25$ eggs at $35^{\circ} \mathrm{C}$, followed by $59.8 \pm 3.25$ eggs and $60.11 \pm 4.25$ eggs at 27 and $31^{\circ} \mathrm{C}$, respectively. The sex ratio was $1: 19$ (male: female) at $29^{\circ} \mathrm{C}$ and $1: 10$ at $27^{\circ} \mathrm{C}$, followed by $1: 6$ and $1: 04$ at $31^{\circ} \mathrm{C}$ and $35^{\circ} \mathrm{C}$, respectively. Males of ambrosia beetle could not fly and were used solely for mating purposes only.

\section{Correlation of life-history traits and different temperature regimes}

Figure 1 represents the correlation between different temperatures and average developmental period (days) from egg to adult of the bark beetle $X$. crassiusculus. The regression equation was $\mathrm{y}=-0.5856 \mathrm{x}+79.712$ and the correlation coefficient was $\mathrm{R}^{2}=0.3134$. Developmental period (days) was negatively correlated with temperature. Furthermore, developmental period (days) fluctuated with the temperature; as temperature decreased, the developmental period increased. The same trend was observed in relation to the ovipositional period (days) and fecundity/female as they were also negatively correlated with temperature. The regression equation for the ovipositional period was: $\mathrm{y}=-0.3534 \mathrm{x}+37.325$ and correlation coefficient was $\mathrm{R}^{2}=0.1588$, when temperature increased the ovipositional period decreased (Figure 2).

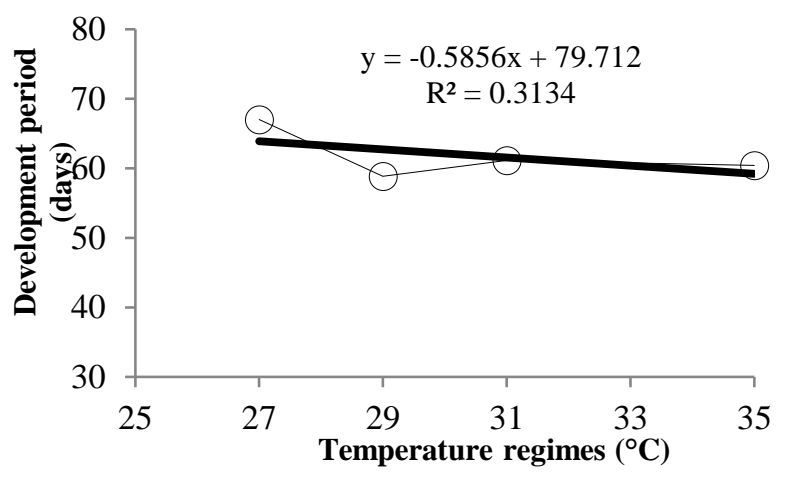

Figure 1. Correlation between developmental period (days) and different temperature regimes used.

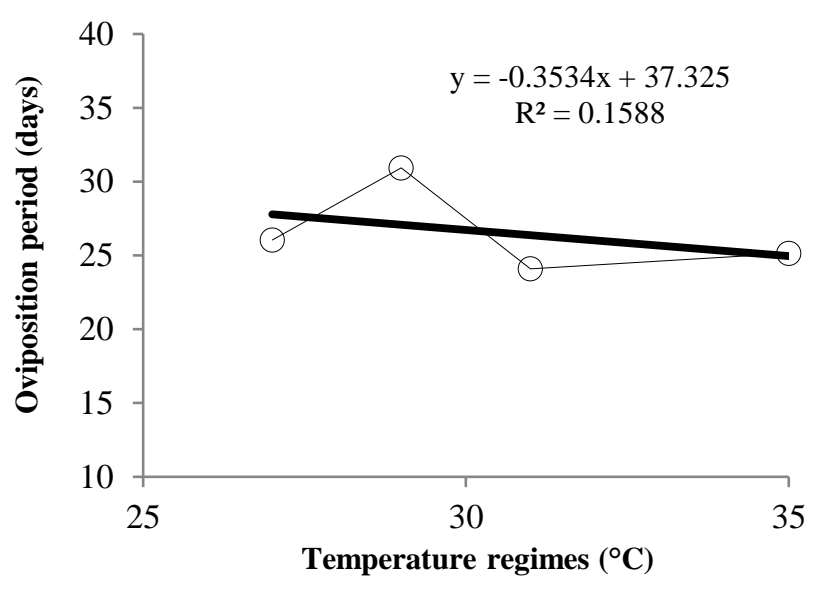

Figure 2. Correlation between the ovipositional period (days) and different temperature regimes used.

Fecundity regression equation was: $\mathrm{y}=-$ $0.8527 x+86.885$ and correlation coefficient $R^{2}=0.3373$, when temperature was decreased to $27^{\circ} \mathrm{C}$, the fecundity of females was lowest, and the fecundity was highest by increasing of temperature to $29^{\circ} \mathrm{C}$. However, when temperature was increased to 31 or $35^{\circ} \mathrm{C}$, the fecundity decreased (Figure 3).

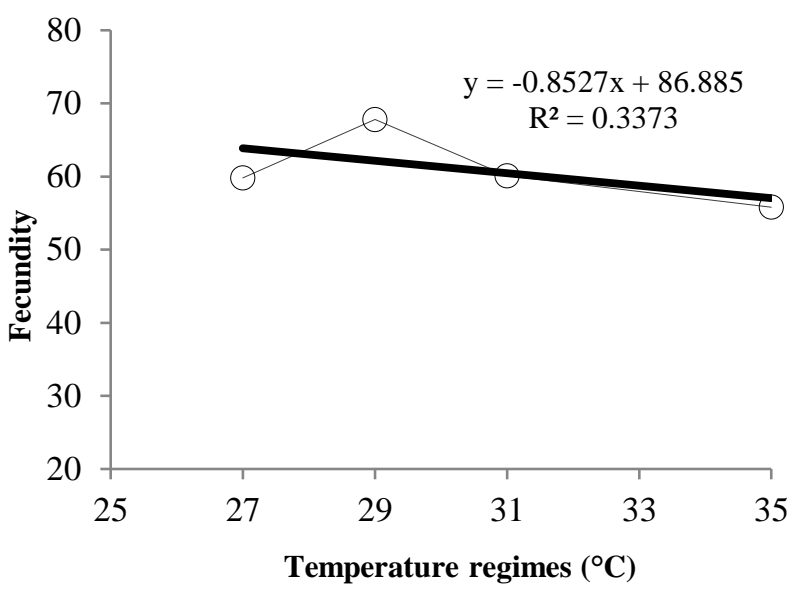

Figure 3. Correlation between female fecundity and different temperature regimes used.

\section{Morphological characteristics}

Significant difference in egg size was observed when the insect was reared at different temperatures. Egg size was largest $(0.41 \pm 0.030 \mathrm{~mm}$ wide, $0.61 \pm 0.041 \mathrm{~mm}$ long $)$ when the female was reared at $29^{\circ} \mathrm{C}$ as compared to females reared at $35^{\circ} \mathrm{C}$. Whereas, smallest size $(0.25 \pm 0.025 \mathrm{~mm}$ wide, $0.53 \pm 0.033 \mathrm{~mm}$ long) was observed when the insect was reared at $35^{\circ} \mathrm{C}$, with significant differences among treatments $(\mathrm{t}=4.13, \mathrm{~F}=0.33 ; \mathrm{df}=119, \mathrm{P}<0.007)$. In shape, eggs were rod-shaped, shining and soft white in color, with both ends largely curved (Table 2). 
Table 2. Mean life stage body size $( \pm \mathrm{SE})$ of the insect $X$. crassiusculus when reared at different temperatures.

\begin{tabular}{lccccc}
\hline & \multicolumn{4}{c}{ Body measurement (mm) (n=20) } \\
\cline { 2 - 3 } \cline { 2 - 3 } \cline { 5 - 6 } Life stage & \multicolumn{2}{c}{ Width } & $\mathbf{2 5}^{\circ} \mathbf{C}$ & & \multicolumn{2}{c}{ Length } \\
\cline { 2 - 3 } \cline { 5 - 6 } Egg & $0.41 \pm 0.030$ & $0.25 \pm 0.025$ & & $0.61 \pm 0.041$ & $0.53 \pm 0.033$ \\
$1^{\text {st }}$ larval Instar & $0.39 \pm 0.051$ & $0.21 \pm 0.039$ & & $0.77 \pm 0.010$ & $0.63 \pm 0.004$ \\
$5^{\text {th }}$ Instar/ Full grown & $0.71 \pm 0.043$ & $0.65 \pm 0.025$ & & $3.01 \pm 0.099$ & $2.06 \pm 0.070$ \\
Pupa & $0.89 \pm 0.064$ & $0.78 \pm 0.044$ & & $2.82 \pm 0.089$ & $2.01 \pm 0.069$ \\
Adult & $0.92 \pm 0.002$ & $0.69 \pm 0.007$ & & $1.99 \pm 0.098$ & $1.58 \pm 0.077$ \\
\hline
\end{tabular}

The larvae were white in color, legless and slightly curved. The size of $1^{\text {st }}$ instar larvae was $0.39 \pm 0.051 \mathrm{~mm}$ wide and $0.77 \pm 0.010 \mathrm{~mm}$ long when reared at $29^{\circ} \mathrm{C}$, and was smaller $(0.21 \pm 0.039 \mathrm{~mm}$ wide and $0.63 \pm 0.004 \mathrm{~mm}$ long $)$ when reared at $35^{\circ} \mathrm{C}$, with significant difference among treatments $(\mathrm{t}=5.09, \mathrm{~F}=0.54 ; \mathrm{df}=115, \mathrm{P}<0.001)$. The mean size of $5^{\text {th }}$ instar (full grown larvae) was $0.71 \pm 0.043 \mathrm{~mm}$ wide and $3.01 \pm 0.099 \mathrm{~mm}$ long when reared at $29^{\circ} \mathrm{C}$, and $0.65 \pm 0.025 \mathrm{~mm}$ wide and $2.06 \pm 0.070 \mathrm{~mm}$ long when reared at $35^{\circ} \mathrm{C}$. The t-test showed a significant difference between the temperature treatments $(\mathrm{t}=6.01, \mathrm{~F}=0.56 ; \mathrm{df}=75$, $\mathrm{P}<0.021)$. The new white pupae turned to light brown just before adult emergence and with a mean size of $0.89 \pm 0.064$ $\mathrm{mm}$ wide and $2.82 \pm 0.089 \mathrm{~mm}$ long when reared at at $29^{\circ} \mathrm{C}$ and $0.78 \pm 0.044 \mathrm{~mm}$ wide and $2.01 \pm 0.069 \mathrm{~mm}$ long when reared at $35^{\circ} \mathrm{C}$, with significant difference in pupa's width $(\mathrm{t}=3.03, \mathrm{~F}=0.45 ; \mathrm{df}=59, \mathrm{P}<0.037)$ but without significant difference in pupa's length $(\mathrm{t}=0.25, \mathrm{~F}=0.16 ; \mathrm{df}=19, \mathrm{P}<0.747)$. The adults were cylindrical with an average body size of $0.92 \pm 0.002 \mathrm{~mm}$ wide and $1.99 \pm 0.098 \mathrm{~mm}$ long when reared at $29^{\circ} \mathrm{C}$ and $0.69 \pm 0.007 \mathrm{~mm}$ wide and $1.58 \pm 0.077 \mathrm{~mm}$ long when reared at $35^{\circ} \mathrm{C}$, with significant differences between the two treatments $(\mathrm{t}=4.20, \mathrm{~F}=0.53 ; \mathrm{df}=198, \mathrm{P}<0.001)$ (Table 2).

\section{Discussion}

All developmental stages from eggs to adults were affected by temperature. Results obtained were in agreement with earlier reports (Iqbal et al., 2007; Ranger et al., 2013) which indicated that temperature variations had an influence on the life cycle of ambrosia bark beetles. Usually, incubation period of bark beetle eggs depend on substrate (i.e., artificial diet vs. natural host) and temperature (Carrillo et al., 2014). However, Ranger et al. (2016) investigated the effect of different temperature levels on the life stages duration of the ambrosia beetle, reported that eggs hatched in 7-14 days and larvae pupated in $11-23$ days at $29^{\circ} \mathrm{C}$, but when reared at $22-$ $24^{\circ} \mathrm{C}$ the eggs hatched in 14-35 days and the larvae pupated in 21-35 days. Likewise, earlier results on the biology of $X$. crassiusculus indicated better sex ratio, high fecundity rate, hatching ability and short life cycle when the beetle was reared at $29^{\circ} \mathrm{C}$ as compared to 27,31 and $35^{\circ} \mathrm{C}$. The maximum number of eggs laid was $67.8 \pm 4.25$ at $29^{\circ} \mathrm{C}$. Kazmi et al., (2005) reared H. mangiferae, X. glabratus and $X$. crassiusculus at three temperature levels and the results obtained were significantly different from each other. Furthermore, Carrillo et al., (2013) conducted laboratory experiments at two temperature levels and examined the life history traits of the bark beetle. The findings partially agree with those of Masood et al., (2009), who conducted an experiment under controlled laboratory conditions on the life cycle of mango bark beetle, Hypocryphalus mangiferae. He reported that at $25^{\circ} \mathrm{C}$, larval duration was completed within $16.90 \pm 2.12$ days, pupal period lasted $3.85 \pm 1.41$ days and the adults emerged and survived for $22.9 \pm 3.53$ days. The female was observed to lay more eggs up to 27 days when reared at $29^{\circ} \mathrm{C}$, as compared to other temperature regimes. These results agree with those reported by Roeper et al., (1980). Many other workers investigated the effect of environmental factors on the life stages of different bark beetle spp., especially temperature (Werle et al., 2016; Ranger et al., 2016; Beaver and Liu, 2010; Masood et al., 2009; Steininger et al., 2015). The differences between these reported results (developmental times, fecundity and morphological characteristics) and those of the present study may be due to different species investigated, use of different artificial diets, natural hosts and different temperature regimes. However, all indicated the influence of temperature on the biological parameters of the mango bark beetle.

It can be concluded from the present study that the highest fecundity with a shortest egg incubation period (days), maximum hatching, faster larval and pupal development time, highest female ratio, and body size increase were recorded when the $X$. crassiusculus was reared at $29^{\circ} \mathrm{C}$ as compared to other temperatures. Accordingly, the rearing temperature of $29^{\circ} \mathrm{C}$ was found to be the most favorable (Optimum) temperature for $X$. crassiusculus beetle's development and reproduction.

\section{Acknowledgments}

The present work is part of $\mathrm{Ph}$. D. thesis research conducted by the first author under the supervision of Abdul Ghani Lanjar at the Department of Plant Protection, Sindh Agriculture University, Tandojam-Pakistan. The first author is thankful to all members of the supervisory committee for guidance. 


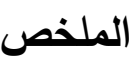

قرشي، خالد حسين، عبد الوحيد سولانجي، عبد الغني لنجر ، جان محمد مري، سجاد علي خوهرو وأسلام بوكيرو. 2021. العناصر الحياتية لخنفساء

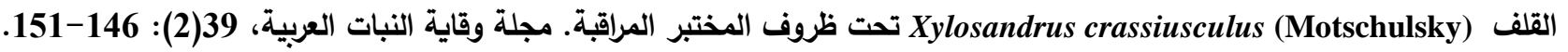
تمت دراسة العناصر الحياتية لخنفساء القلف (Coleoptera: Curculionidae: Scolytinae) Xylosandrus crassiusculus (Motschulsky) عند مستويات حرارة مختلفة (27، 29، 31 و 35 س). وصل طول فترة وضع البيض للإناث 30.93 يوماً عند حرارة 29×س. وضعت الإناث 6.71 بيضة/اليوم في 6.99 لطخة

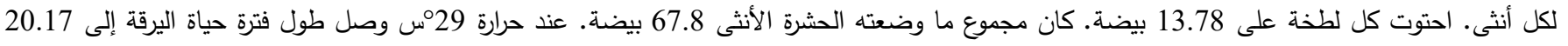
يوماً، فترة حياة العذراء 5.03 يوماً وفترة حياة الحشرة الكاملة 29.44 يوماً. كان هناك فرق معنوي لعناصر الحياة المختلفة للحشرة عند تربيتها عند حرارة 29 عس مقارنة

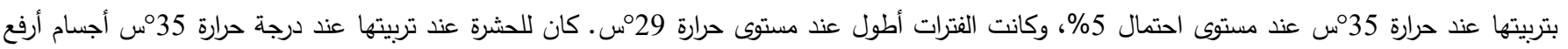
وكانت أقل حجماً. كما كان ارتباط طول فترات الأطوار المختلفة، بما فيها فترة وضع البيض، ونلف سلبياً مع درجة الحرارة. كلمات مفتاحية: Xylosandrus crassiusculus، عناصر حياتية، خنفساء القلف، درجة الحرارة.

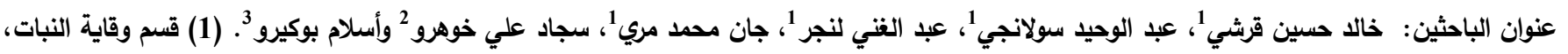

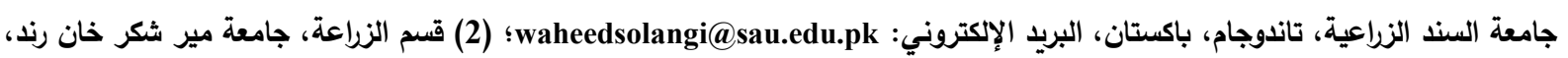
سيبي، بلوشتان، باكستان، (3) قسم الحشرات، جامعة الشند الزراعية، تاندوجام، باكستان.

\section{References}

Beaver, R.A. and L.Y. Liu. 2010. An annotated synopsis of Taiwanese bark and ambrosia beetles, with new synonymy, new combinations and new records (Coleoptera: Curculionidae: Scolytinae). Zootaxa, 2602: 1-47. https://doi.org/10.11646/zootaxa.2602.1.1

Brown, K.A., F.N. Scatena and J. Gurevich. 2006. Effect of an invasive tree on community structure and diversity in a tropical forest in Puerto Rico. Forest Ecology and Management, 226: 145-152. https://doi.org/10.1016/j.foreco.2006.01.031

Carrillo, D., R.E. Duncan, J.N. Ploetz, A.F. Campbell, R.C. Ploetz and J.E. Pena. 2014. Lateral transfer of a phytopathogenic symbiont among native and exotic ambrosia beetles. Plant Pathology, 63: 54-62. https://doi.org/10.1111/ppa.12073

Fernandez, F.M.M., J.A.P. Alonso and J.M.S. Costas. 1999. Oviposition and development of immature stages of Tomicus minor (Coleoptera, Scolytidae). Agriculture and Forest Entomology, 1: 97-102. https://doi.org/10.1046/j.1461-9563.1999.00012.x

Gandhi, K.J.K., A.I. Cognato, D.M. Lightle, B.J. Mosley, D.G. Nielsen and D.A. Herms. 2010. Species composition, seasonal activity, and semiochemical response of native and exotic bark and ambrosia beetles (Coleoptera: Curculionidae: Scolytinae) in northeastern Ohio. Journal of Economic Entomology, 103: 1187-1195. https://doi.org/10.1603/ec10026

Gurpreet, S., B. John, C. Paule, K.S. Mclean and J. Pena. 2013. Life cycle, development, and culture of Xyleborus glabratus (Coleoptera: Curculionidae: Scolytinae). Florida Entomologist, 96: 1158-1167. https://doi.org/10.1653/024.096.0357

Hanula, J.L., A.E. Mayfield, S.W. Fraedrich and R.J. Rabaglia. 2008. Biology and host association of redbay ambrosia beetle, Xyleborus glabratus (Coleoptera: Curculionidae: Scolytinae), exotic vector of laurel wilt killing redbay (Persea borbonia) trees in the Southeastern United States. Journal Economic Entomology, 101: 1276-1286. https://doi.org/10.1603/00220493(2008)101[1276:BAHAOR]2.0.CO;2

Iqbal, Z., E.E. Valeem, M. Shahbaz, K. Ahmad, Z.I. Khan, M.T. Malik and M. Danish. 2007. Determination of different decline disorders in mango orchards of the Punjab, Pakistan. Pakistan Journal of Botany, 39: 1313-1318.

Jiskani, M.M., M.A.Pathan, K.H. Wagan and M.I. Khaskheli. 2007. Documentation of identified and to be identified disease of mango in Sindh, Pakistan. Pages 13-14. In: Proceedings of International Symposium on 'Prospects of Horticultural Industry in Pakistan (Future challenges \& Production Prospects). March 28-30, 2007, Institute of Horticultural Sciences, University of Agriculture Faisalabad- Pakistan.

Kazmi, M.R., F.S. Fateh, K. Majeed, A.M. Kashkhely, I. Hussain, I. Ahmad and A. Jabeen. 2005. Incidence and etiology of mango sudden death phenomenon in Pakistan. Pakistan Journal Phytopathology, 17: 154158.

Kendra, P.E., W.S. Montgomery, J. Niogret, M.A. Deyrup, L. Guillén and N.D. Epsky. 2012. Xyleborus glabratus, $X$. affinis, and $X$. ferrugineus (Coloeptera: Curculionidae: Scolytinae): Electroantennogram responses to host-based attractants and temporal patterns in host-seeking flight. Environmental Entomology, 41: 1597-1605. https://doi.org/10.1603/EN12164

Khuhro, R.D., S.M. Nizamani, Q.D. Abbasi, G.M. Rahoo and M.M. Jiskani. 2005. Asian ambrosia beetle: a new insect pest in Sindh Pakistan. Pakistan Journal of Agriculture, Agricultural Engineering, Veterinary Sciences, 21: 44-49. 
Masood, A., S. Saeed, A. Sajjad and M. Ali. 2009. Life Cycle and Biology of Mango Bark Beetle, Hypocryphalus mangiferae (Stebbing), A Possible Vector of Mango Sudden Death Disease in Pakistan. Pakistan Journal Zoology, 41: 281-288.

Masood, A., S. Saeed, M.T. Malik, Naeem Iqbal and M.R. Kazmi. 2010. Methodology for the evaluation of symptoms severity of mango sudden death syndrome in Pakistan. Pakistan Journal of Botany, 42: 1289-1299.

Mizell, R.F. and T.C. Riddle. 2004. Evaluation of insecticides to control Asian ambrosia beetle, Xylosandrus crassiusculus. Pages 152-155. In: Proceedings of 49th Annual Southern Nursery Association Research Conference. B.L. James (ed.). Southern Nursery Association, Marietta, GA, USA

Ranger, C.M., M.E. Reding, A.B. Persad and D.A. Herms. 2010. Ability of stress-related volatiles to attract and induce attacks by Xylosandrus germanus (Coleoptera: Curculionidae, Scolytinae) and other ambrosia beetles. Agriculture and Forest Entomology, 12: 177-185. https://doi.org/10.1111/j.1461-9563.2009.00469.x

Ranger, C.M., M.E. Reding, P. Schultz, J. Oliver, S. Frank, K. Addesso, J.H. Chong, B.J. Sampson, C.T. Werle, S. Gill and C. Krause. 2016. Biology, ecology and management of nonnative ambrosia beetles (Coleoptera: Curculionidae: Scolytinae) in ornamental tree nurseries. Journal of Integrated Pest Management, 7: 1-23. https://doi.org/10.1093/jipm/pmw005

Received: April 21, 2020; Accepted: May 19, 2021
Ranger, C.M., M.E. Reding, P.B. Schultz and J.B. Oliver. 2013. Ambrosia beetle (Coleoptera: Curculionidae) responses to volatile emissions associated with ethanolinjected Magnolia virginiana. Environmental Entomology, 41: 636-647. https://doi.org/10.1603/EN11299

Roeper, R.A., L.M. Treeful, K.M. Brien R.A. Foote and M.A. Bunce. 1980. Life history of the ambrosia beetle Xyleborus affinis (Coleoptera: Scolytidae) from in-vitro culture. Great Lakes Entomologist, 13: 141145

Saeed, S., A. Masood, H. Ali and Y.J. Kwon. 2011. Comparative efficacy of different pesticides against mango bark beetle Hypocryphalus mangiferae Stebbing (Coleoptera: Scolytidae). Entomological Research, 41: 142-150. https://doi.org/10.1111/j.1748-5967.2011.00329.x

Steininger, M.S., J. Hulcr, M. Sigut and A. Lucky. 2015. Simple and efficient trap for bark and ambrosia beetles (Coleoptera: Curculionidae) to facilitate invasive species monitoring and citizen involvement. Journal of Economic Entomology, 108: 1118-1123.

https://doi.org/10.1093/jee/tov014

Werle, C.T., K.M. Addesso, B.J. Sampson, J.B. Oliver and J.J. Adamczyk. 2016. Integrating kaolin clay for ambrosia beetle (Coleoptera: Curculionidae: Scolytinae) management in ornamental tree nurseries. Journal of Insect Science, 1: 94-98.

تاريخ الاستلام: 2020/4/21؛ تاريخ الموافقة على النشر: 2021/5/19 